\title{
Assessment of stiffened angle shear connector under monotonic and fully reversed cyclic loading
}

Mahdi Shariati, Ali Toghroli, Abdolrahim Jalali and Zainah Ibrahim

\begin{abstract}
An experimental study was performed to investigate the behaviour of a newly proposed shear connector named as stiffened angle shear connector. The connector is proposed to fulfil the deficiency of angle shear connector based on previous researches have been conducted by the authors[1-3]. The connector has been tested experimentally under monotonic and fully reversed low cyclic fatigue loading. In each series, four push-out specimens were tested covering different sizes of stiffened angle shear connector and different types of loadings. Later the comparison of the shear connectors' performance in the case of with and without stiffener has been conducted. The results show not adequate ductility of newly proposed shear connectors, but much better performance in case of shear strength. All specimens have the connectors' fracture type of failure since high strength concrete has been chosen to cause this fracture for better investigation. The newly proposed shear connector showed Shear strength degradation of 7.9-13.7\% for specimens with full height stiffener comparing to non-stiffened shear connectors and 14.2-26.6\% for those specimens with half height stiffener. Full height stiffener has increased in shear strength between 157.1-233.1\% and half height stiffener has increased in shear strength between 45.1-150.6\% under monotonic loading. These ranges were between 161.8$305.4 \%$ for full height and 19.0-225.1\% for half height stiffener under fully reversed low cyclic fatigue loading. Generally, specimens with stiffeners.
\end{abstract}

Keywords - Shear connector; Stiffened angle connector; Shear resistance; Push-out test; Cyclic loading; Ductility; Fully reversed; Low cyclic fatigue loading;

\section{Introduction}

Steel-concrete composite constructions have been used in buildings and bridges since the early 1920s [4-6].

Mahdi Shariati

University of Malaya,

Malaysia

Ali Toghroli

University of Malaya,

Malaysia

Abdolrahim Jalali

University of Tabriz,

Iran

Zainah Ibrahim

University of Malaya,

Malaysia

The component that assures the shear transfer between the steel profile and the concrete slab is the shear connector [7, 8].
The increase of surface roughness might improve the strength of fully composite steel-concrete sandwich beam element [10].

Shear connector is a structural component which is used as a shear resistance in steel-concrete interface in composite structures. The performance of the shear connector has a great influence on the behavior of the composite beam [9]. Due to the complexity of the partial interaction mechanism of the shear connector, steel and concrete are generally assumed to be fully interacted in design.

However, the design will be more rational if partial interaction between steel and concrete which is represented by shear force-relative displacement relationship of the shear connector is taken into account [11]. Headed studs and Perfobond shear connectors are the most popular shear connectors. Due to the limitations in the performance of headed studs and Perfobond shear connectors, the use of replacement connectors like angle shear connectors has been recommended mainly in developing countries [12]. They are less expensive and more practical because of the lack of one flange [12]. With regard to load carrying capacity, the angle connectors show higher capacity and with the use of the conventional, reliable welding system, it could be welded easily to steel beam.

Recently, a few studies have been done to assess the behavior of angle shear connectors by the authors of this research and also researchers all around the world [2, 3, 9, 1219] using the push- out test which has been widely performed to measure the shear strength of interaction between steel and concrete slab in composite floor systems. Many researches have used this method of testing $[12,15,20,21]$.

In this study, to achieve the benefits of angle connectors with higher strength, a stiffened angle shear connector is proposed. The geometry and details of this stiffened shear connector are shown in "Fig. 1". The angle connector welded onto the flange of a steel I-beam with an attached triangle stiffener. Different size of stiffened angle shear connectors is considered in this study as shown in Table 1. The same thickness as the flange thickness of angle connector has been chosen for relative connectors. The behavior of this stiffened shear connector under both the monotonic and fully reversed low cyclic fatigue loading is investigated.

This study comprises of the results experimental push-out tests performed in two series under monotonic and fully reversed low cyclic fatigue loading. Different parameters affecting the behavior of this shear connector are assessed. The behavior of the specimens is studied in terms of load-slip analysis, and the effect of geometric properties. High compressive strength enough of concrete was used to avoid having concrete crushing mode of failure in this research so that the study will focus only on the behavior of stiffened angle shear connector. 


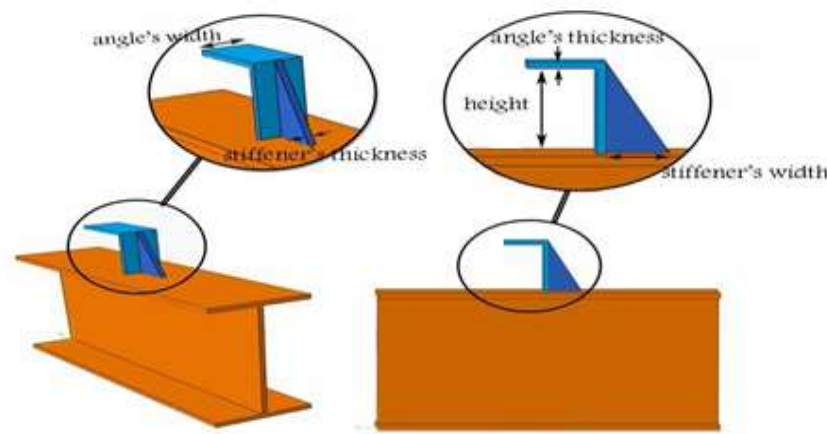

Figure 1: Geometry and details of stiffened shear connector

\section{Test program}

\section{Specimen details}

In this study sixteen push-out tests divided into two series under monotonic and fully reversed low cyclic fatigue loading were tested as shown in Table 1. Eight specimens with full height and half height stiffener were considered under monotonic loading and another similar eight specimens were considered under fully reversed low cyclic fatigue loading. Push-out specimens consist of steel I beam with two slabs attached to each flange of the beam. One stiffened angle shear connector was welded to each beam flange and two layers of steel bars with four $10 \mathrm{~mm}$ diameter steel bar hoops were applied in two perpendicular directions for all slabs.

Table 1: Specimen's geometry properties

\begin{tabular}{|c|c|c|c|c|c|c|}
\hline & \multicolumn{3}{|c|}{ Angle shear connector } & \multicolumn{3}{c|}{ Stiffener } \\
\hline Specimen & Height & Length & Thickness & Height & Length & Thickness \\
\hline A7530-F & 75 & 50 & 6 & 75 & 75 & 5.5 \\
\hline A7550-F & 75 & 50 & 6 & 75 & 75 & 5.5 \\
\hline A7530-H & 75 & 50 & 6 & 37.5 & 37.5 & 5.5 \\
\hline A7550-H & 75 & 50 & 6 & 37.5 & 37.5 & 5.5 \\
\hline A10030-F & 100 & 50 & 7 & 100 & 100 & 7 \\
\hline A10050-F & 100 & 50 & 7 & 100 & 100 & 7 \\
\hline A10030-H & 100 & 50 & 7 & 50 & 50 & 7 \\
\hline A10050-H & 100 & 50 & 7 & 50 & 50 & 7 \\
\hline
\end{tabular}

\section{A. Concrete materials and mix proportions}

Air-dry condition aggregates were used in concrete mixes. Fine aggregate was graded silica sands and a maximum nominal size of $4.75 \mathrm{~mm}$ and coarse aggregate was crushed granite with maximum nominal size of $10 \mathrm{~mm}$. The particle size analysis of the fine aggregates is given in Table 2 [22].

The cement used in all mixes was Ordinary Portland Cement (OPC). To attain acceptable workability, super plasticizer (SP) was used in both mixes. The SP used in this investigation is Rheobuild 1100.

The specific gravity of the SP is approximately 1.195 , and is dark brown in color with a $\mathrm{pH}$ within the range of $6.0-9.0$
[23]. The concrete slab size limitation is the reason for using short lengths of connectors.

Table 2. Analysis of particle size of silica sand (SS) as BS 822: Clause 11.

\begin{tabular}{|c|c|c|c|c|c|c|c|}
\hline 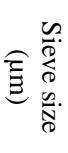 & $\frac{2}{0}$ & $\begin{array}{l}\sum \\
\infty \\
\infty \\
+ \\
\sum \\
\infty \\
\infty 10\end{array}$ & 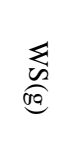 & 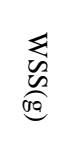 & $\frac{\pi}{Q}$ & 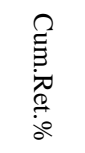 & $\begin{array}{l}\overrightarrow{0} \\
\dot{w} \\
d^{\circ}\end{array}$ \\
\hline 4750 & $3 / 16$ in & 409.9 & 408.3 & 1.6 & 0.32 & 0.032 & 99.68 \\
\hline 2360 & NO.7 & 462.3 & 375.7 & 86.6 & 17.33 & 17.65 & 82.35 \\
\hline 1180 & NO.14 & 437.2 & 343.0 & 94.2 & 18.85 & 36.5 & 63.50 \\
\hline 600 & NO. 25 & 450.7 & 316.2 & 134.5 & 26.93 & 63.42 & 36.58 \\
\hline 300 & NO.52 & 379.1 & 288.7 & 90.4 & 18.09 & 81.51 & 18.49 \\
\hline 150 & NO. 100 & 322.1 & 274.8 & 47.3 & 9.47 & 90.99 & 9.02 \\
\hline 75 & NO.200 & 309.9 & 275.2 & 34.7 & 6.94 & 97.92 & 2.08 \\
\hline Pan & - & 250.8 & 240.4 & 10.4 & 2.08 & - & 0.00 \\
\hline total & & & & 499.7 & & 388.31 & \\
\hline
\end{tabular}

Fineness modulus $=388.31 / 100=3.88$; Water absorption for silica sand is $0.93 \%$; WSS=Silica sand weight; WS $=$ Sieve weight; Cum. Ret $=$ Cumulative retained

\section{B. Concrete casting and testing}

All of the push-out specimens were cast in a horizontal position similar to the site situations. A reliable quality of concrete for both sides of specimen slabs was assumed as well. All specimens were cured in water for 28 days before testing. To obtain the compressive strength, standard cylinders with a diameter of $150 \mathrm{~mm}$ and a length of $300 \mathrm{~mm}$ and standard cubes with a length of $100 \mathrm{~mm}$ were cast with the push-out specimens simultaneously. All cylinders and cubes were cured in water till the day of testing. The concrete strength was achieved from the cylinder and the cube compression tests together. The requirements of the ASTM C39 [24] were used for the compressive strength test procedure and the mean value of the compression strength of concrete was used in the calculations. In this study the compressive strength of concrete was used to be 63Mpa to avoid having concrete crushing mode of failure so that the study will focus only on behavior of stiffened angle shear connector.

\section{c. Symbolization}

In the symbolization of the specimens, the first letter indicates the steel profile type of shear connector mean A as angle shear connector. The first two digits indicate the height and the last two digits indicate the length of the shear connector in the concrete slabs. The letters $\mathrm{F}$ and $\mathrm{H}$ specify full height and half height of respective stiffeners. Those letters $\mathrm{M}$ and $\mathrm{C}$ specify monotonic and fully reversed low cyclic fatigue loading. "Fig. 2" shows the details of a typical specimen. 

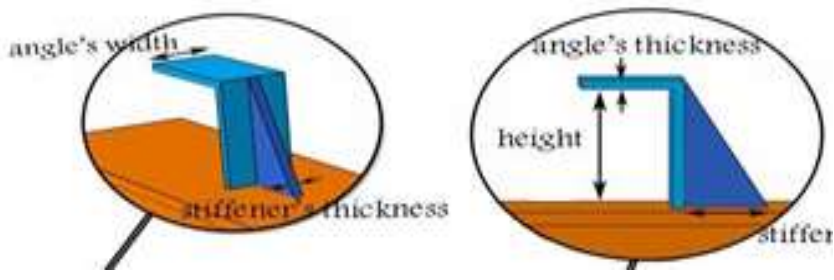

Fig. 2 Details of a typical specimen

\section{Test procedure}

A universal testing machine was used to apply load as shown in "Fig. 3". For loading procedures, the previous procedure executed by the author of this research has been used $[9,12,14,15]$. Monotonic loading involved a slow increment of the load until failure. It's worth to mention that, in reversed cycling loading procedure all specimens were rearranged earlier to every loading procedure by turning the specimens and then loading the upper concrete faces. The displacement-control method with a rate of $0.04 \mathrm{~mm} / \mathrm{s}$ was used for recording the load- slip results of push out tests [12].
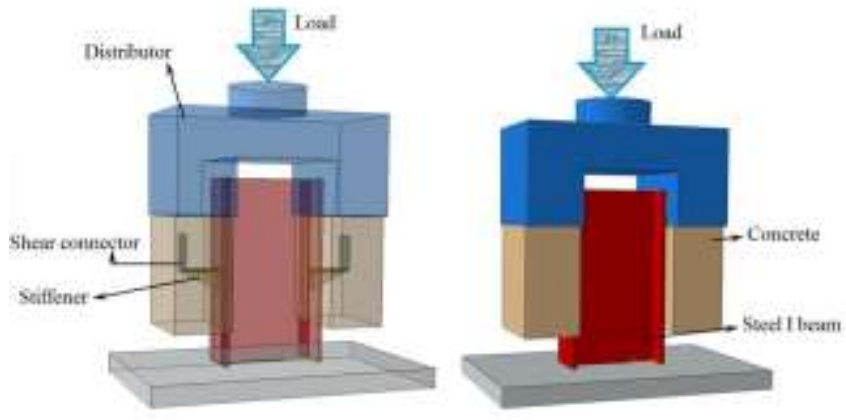

Figure 3: Test setup of push out test

\section{Result and discussion}

Basically, two types of failure of shear connectors are defined in the push-out specimens. They are connector's failure and concrete crushing splitting, respectively [25, 26]. For this study, to study only the behavior of stiffened angle shear connector the, only connector failure mode was settled to be achieved for both the monotonic and fully reversed low cyclic fatigue loading as shown in "Fig. 4".

Usually, concrete crushing around the connectors occurs in these types of failure mode, but due to the less ductility of stiffened angle shear connector, this factor was not seen much. Only some cracks formed around the surface of connectors and in a direction parallel to the steel I-beam.

From the load-slip curve for all specimens, it has been reported that the ultimate strength of composite beams depends on the strength and ductility of the shear connection. Therefore the load-slip behavior of shear connector is considered important when a displacement is applied to the connector. The load-slip curve of specimens with the failure of the connector fracture type came to a sudden end.

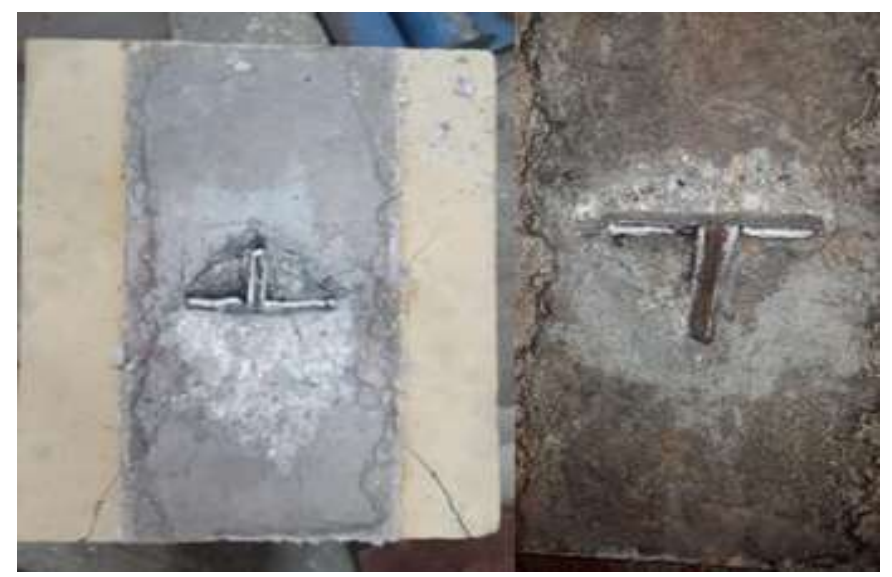

Figure 4. Fracture failure for stiffened C-shaped angle shear connector

The ultimate shear capacity of the connector is related to the compressive strength of concrete for concrete-related failures. A growth in load capacity for angle shear connectors, with the square root of compressive strength of the concrete, can be seen in this study as reported in other studies.

The load-slip curve for one shear connector was employed to extract the mechanical properties of that connector. The slip occurred between the steel I-beam and the concrete block. Based on Eurocode 4, suggesting that a connector may be taken as ductile if the characteristic slip capacity is at least 6 $\mathrm{mm}$, it can be concluded that stiffened angle shear connectors are not sufficiently ductile in the peak load for the monotonic loading. Almost all the specimens experienced slip less than 6 $\mathrm{mm}$ which is required for ductility criteria of shear connectors. By considering the load-slip graph as shown in "Fig. 5", it could be concluded that although the stiffener caused the enhancement of shear load capacity, it leads to reducing of ductility as compared with none stiffened C-shaped angle connector which has been done by Shariati [1]. Analyzing the load-slip curves of specimens with stiffened angle shear connectors when subjected to the monotonic load, a sudden termination of the load-slip curve was observed. Comparing to non-stiffened shear connectors, one of the main differences in the behavior is that almost all stiffened specimens experience much less ductile performance, but much more shear strength in the push-out tests.

As shown by the results, the stiffness of the stiffened angle shear connectors is enhanced due to usage of stiffener. By increasing the stiffness, the ultimate load carry capacity rises and ductility drops. Hence, stiffened C-shaped angle shear connectors can play a significant role where strength, rather than ductility of the shear connection governs the design.

The load carrying capacity decreases when half height stiffener is used. The displacement of fully stiffened angle shear connector increases, insignificantly. There is a significant growth in displacement of half stiffened angle connector by approximately $50 \%$. Besides, the stiffened angle connectors with a longer leg length had better shear connector resistance as compared with those with shorter leg length. This finding was most likely caused by stress concentrations generated by the interaction between the stress areas of the connector and the concrete. Table 3 shows the ultimate shear capacity and slip for all specimens and respective shear 
strength degradation comparing to half and full height stiffened shear connector. For this comparison the results of previously published research by the author [1] on behavior of angle shear connector without any stiffener have been used.

Table 3. The analysis of ultimate shear capacity and slip for all specimens

\begin{tabular}{|c|c|c|c|c|}
\hline Specimen & $\begin{array}{c}\text { Failure } \\
\text { Load } \\
(\mathrm{kN})\end{array}$ & $\begin{array}{l}\text { Cyclic Strength } \\
\text { Degradation } \\
(\%)\end{array}$ & $\begin{array}{c}\text { Strength } \\
\text { differentiation } \\
(\%)\end{array}$ & $\underset{(\mathrm{mm})}{\text { Slip }}$ \\
\hline $\begin{array}{c}\text { A7530-M } \\
\text { (Shariati et al. } \\
\text { 2014) }\end{array}$ & 69.6 & \multirow{2}{*}{8.8} & \multirow[b]{2}{*}{ - } & 1.5 \\
\hline $\begin{array}{c}\text { A7530-C } \\
\text { (Shariati et al. } \\
\text { 2014) }\end{array}$ & 63.5 & & & 1.0 \\
\hline A7530-F-M & 224.1 & \multirow{2}{*}{10.7} & 223.9 & 0.5 \\
\hline A7530-F-C & 200.2 & & 215.3 & 1.0 \\
\hline A7530-H-M & 101.0 & \multirow[b]{2}{*}{25.1} & 45.1 & 0.5 \\
\hline A7530-H-C & 75.6 & & 19.0 & 0.5 \\
\hline $\begin{array}{c}\text { A7550-M } \\
\text { (Shariati et al. } \\
\text { 2014) }\end{array}$ & 109.6 & \multirow{2}{*}{11.7} & \multirow[b]{2}{*}{ - } & 1.5 \\
\hline $\begin{array}{c}\text { A7550-C } \\
\text { (Shariati et al. } \\
\text { 2014) }\end{array}$ & 96.8 & & & 1.0 \\
\hline A7550-F-M & 281.8 & \multirow{2}{*}{10.0} & 157.1 & 0.5 \\
\hline A7550-F-C & 253.4 & & 161.8 & 0.5 \\
\hline A7550-H-M & 164.8 & \multirow{2}{*}{25.1} & 50.36 & 1.0 \\
\hline A7550-H-C & 123.5 & & 27.6 & 1.5 \\
\hline $\begin{array}{c}\text { A10030-M } \\
\text { (Shariati et al. } \\
\text { 2014) }\end{array}$ & 77.9 & \multirow{2}{*}{33.1} & \multirow[b]{2}{*}{ - } & 1.5 \\
\hline $\begin{array}{c}\text { A10030-C } \\
\text { (Shariati et al. } \\
\text { 2014) }\end{array}$ & 52.1 & & & 0.5 \\
\hline A10030-F-M & 259.5 & \multirow{2}{*}{13.7} & 233.1 & 2.0 \\
\hline A10030-F-C & 211.2 & & 305.4 & 1.5 \\
\hline A10030-H-M & 197.3 & \multirow{2}{*}{14.2} & 150.6 & 1.0 \\
\hline A10030-H-C & 169.4 & & 225.1 & 1.0 \\
\hline $\begin{array}{c}\text { A10050-M } \\
\text { (Shariati et al. } \\
\text { 2014) }\end{array}$ & 141.0 & \multirow[b]{2}{*}{24.2} & \multirow[b]{2}{*}{ - } & 2.0 \\
\hline $\begin{array}{c}\text { A10050-C } \\
\text { (Shariati et al. } \\
\text { 2014) }\end{array}$ & 106.9 & & & 1.5 \\
\hline A10050-F-M & 412.4 & \multirow{2}{*}{7.9} & 192.2 & 2.0 \\
\hline A10050-F-C & 379.6 & & 255.1 & 1.0 \\
\hline A10050-H-M & 326.9 & \multirow{2}{*}{26.6} & 131.8 & 1.0 \\
\hline A10050-H-C & 240.2 & & 124.7 & 0.5 \\
\hline
\end{tabular}

By comparing all specimens when the specimens are tested under monotonic and fully reversed low cyclic fatigue loading, it has been found that the ultimate shear capacity has shear strength degradation of $7.9-13.7 \%$ for those specimens with full height stiffener comparing to non-stiffened shear connectors and $14.2-26.6 \%$ for those specimens with half height stiffener comparing to non-stiffened shear connectors.

On the other hand, comparing the pair to pair of the specimens with and without stiffener, in case of monotonic behavior, those specimens with full height stiffener has increased in shear strength between 157.1-233.1\% compared to similar non stiffened shear connectors and those specimens with half height stiffener has increased in shear strength between 45.1-150.6\% comparing to similar non stiffened shear connectors. Considering the fully reversed low cyclic fatigue loading, those specimens with full height stiffener has increasing in shear strength between 161.8-305.4\% comparing to similar non stiffened shear connectors and those specimens with half height stiffener has increased in shear strength between 19.0-225.1\% comparing to similar non stiffened shear connectors.

In view of the slip amount (ductility) for above tested shear connectors, all specimens with stiffeners has less slip when compared to non-stiffened shear connectors even if those specimens without stiffener also do not have sufficient slip to be considered as ductile shear connectors. That's because none of the shear connectors have a slip over $6 \mathrm{~mm}$. Based on Eurocode 4 [18], suggesting that a connector may be taken as ductile if the characteristic slip capacity is at least $6 \mathrm{~mm}$, it can be concluded that stiffened angle shear connectors are not sufficiently ductile in the peak load for the monotonic loading.

\section{v. Conclusion}

Sixteen push-out specimens were tested to examine of behavior of stiffened C-shaped angle connector under monotonic and fully reversed low cyclic fatigue loading. By comparing all specimens when the specimens are tested under monotonic and fully reversed low cyclic fatigue loading, it has been found that the ultimate shear capacity has shear strength degradation of $7.9-13.7 \%$ for those specimens with full height stiffener comparing to non-stiffened shear connectors and $14.2-26.6 \%$ for those specimens with half height stiffener. Full height stiffener has increased in shear strength between 157.1$233.1 \%$ and half height stiffener has increased in shear strength between 45.1-150.6\% under monotonic loading. These ranges were between $161.8-305.4 \%$ for full height and $19.0-225.1 \%$ for half height stiffener under fully reversed low cyclic fatigue loading. Generally, specimens with stiffeners have less slip when compared to non-stiffened shear connectors.

In view of the slip amount (ductility) for above tested shear connectors, all specimens with stiffeners has less slip when compared to non-stiffened shear connectors even if those specimens without stiffener also do not have sufficient slip to be considered as ductile shear connectors.

\section{(1) References}

1. Shariati, A., et al., Experimental assessment of angle shear connectors under monotonic and fully reversed cyclic loading in high strength concrete. Construction and Building Materials, 2014. 52: p. 276-283.

2. Shariati, M., et al., Fatigue energy dissipation and failure analysis of angle shear connectors embedded in high strength concrete. Engineering Failure Analysis, 2014. 41: p. 124-134.

3. Shariati, M., et al., Behaviour of $C$-shaped angle shear connectors under monotonic and fully reversed cyclic loading: An experimental study. Materials \& Design, 2012. 41: p. 67-73.

4. Vianna, J.d.C., et al., Experimental assessment of Perfobond and TPerfobond shear connectors' structural response. Journal of Constructional Steel Research, 2009. 65(2): p. 408-421.

5. Safa, M., et al., Potential of adaptive neuro fuzzy inference system for evaluating the factors affecting steel-concrete composite beam's shear strength. Steel and Composite Structures, An Int'l Journal, 2016. 21(3): p. 679-688.

6. Toghroli, A., et al., Potential of soft computing approach for evaluating the factors affecting the capacity of steel-concrete composite beam. Journal of Intelligent Manufacturing, 2016: p. 1-9.

7. Ver'1ssimo GS, et al., Design and experimental analysis of a new shear 
connector for steel and concrete composite structures. 3rd international conference on bridge maintenance, safety and management., 2006.

8. Chromiak, P. and J. Studnicka, COMPUTER MODEL OF PERFOBOND CONNECTOR.

9. Tahmasbi, F., et al., Shear Capacity of C-Shaped and L-Shaped Angle Shear Connectors. PloS one, 2016. 11(8): p. e0156989.

10. Toghroli, A., et al., Prediction of shear capacity of channel shear connectors using the ANFIS model. Steel and Composite Structures, 2014. 17(5): p. 623-639.

11. Shahabi, S., et al., Performance of shear connectors at elevated temperatures-A review. Steel and Composite Structures, 2016. 20(1): p. 185-203.

12. Shariati, M., et al., Comparative performance of channel and angle shear connectors in high strength concrete composites: An experimental study. Construction and Building Materials, 2016. 120: p. 382-392.

13. Shariati, M., et al., Behavior of V-shaped angle shear connectors: experimental and parametric study. Materials and Structures, 2016. 49(9): p. 3909-3926.

14. Shariati, M., et al., Behavior of V-shaped angle shear connectors: experimental and parametric study. Materials and Structures, 2015: p. 118.

15. Khorramian, K., et al., Behavior of Tilted Angle Shear Connectors. PLoS ONE, 2015. 10(12): p. e0144288.

16. Shariati, A., et al., Experimental assessment of angle shear connectors under monotonic and fully reversed cyclic loading in high strength concrete. Construction and Building Materials, 2014. 52(0): p. 276-283.

17. Shariati, M., et al., Comparison of behaviour between channel and angle shear connectors under monotonic and fully reversed cyclic loading. Construction and Building Materials, 2013. 38(0): p. 582-593.

18. Soty, R. and H. Shima, Formulation for shear force-relative displacement relationship of $L$-shape shear connector in steel-concrete composite structures. Engineering Structures, 2013. 46(0): p. 581-592.

19. Choi, S.M., Fatigue Resistance of Angle Shape Shear Connector used in Steel-Concrete Composite Slab. 2011, PhD Thesis, Graduate School of Engineering of Nagoya University, Japan.

20. Rehman, N., et al., Experimental study on demountable shear connectors in composite slabs with profiled decking. Journal of Constructional Steel Research, 2016. 122: p. 178-189.

21. Nguyen, H., H. Mutsuyoshi, and W. Zatar, Push-out tests for shear connections between UHPFRC slabs and FRP girder. Composite Structures, 2014. 118: p. 528-547.

22. Sajedi, F., et al., Relationships between compressive strength of cementslag mortars under air and water curing regimes. Construction and Building Materials, 2012. 31(0): p. 188-196.

23. Sajedi, F. and H.A. Razak, Comparison of different methods for activation of ordinary Portland cement-slag mortars. Construction and Building Materials, 2011. 25(1): p. 30-38.

24. ASTM, C., 39 (2004) "Standard test method for compressive strength of cylindrical concrete specimens.”. Annual Book of ASTM Standards, 2005.

25. Maleki, S. and M. Mahoutian, Experimental and analytical study on channel shear connectors in fiber-reinforced concrete. Journal of Constructional Steel Research, 2009. 65(8-9): p. 1787-1793.

26. Maleki, S. and S. Bagheri, Behavior of channel shear connectors, Part I: Experimental study. Journal of Constructional Steel Research, 2008. 64 p. $1333-1340$. 